\title{
Business Ethics in Central- and East-Europe, a Short Synopsis
}

\author{
Franz Rupert Hrubi
}

What in the first place attracts attention to a western observer (and he is this also, particularly as an EU-citizen, if he lives in the middle of Central Europe), is the fact that in the countries of the region we are talking about shows a remarkable interest in business ethics (I use this term here in the broad sense of ethics in economic affairs). In Europe this subject started to interest a widespread public from the beginning to the middle of the eighties. Academic as well as managerial circles dealt more or less in detail with ethical problems in business and economy. First professorships for business ethics were founded and the rehabilitation of ethics in economy seemed to proceed unstoppably. But at least ten years after the start of this movement we had to realize that it was stagnating. Business ethics didn't totally disappear, but it was from now on the subject of a relatively constant minority.

Now let's go to the Middle and the East of Europe. In a few of the last month's of the eighties the East Bloc, and with it its prevailing economic and social order, began to vanish. And as, after the purge of universities, a new academic staff have become established, there were indeed surprising much of them thinking highly of business ethics. And that was a really good thing, because it is surely easier to shape an emerging system than to change an established one. To avoid misunderstandings: western economies need urgently enough some more ethics, but in the countries of a beginning transformation, of a fundamental reorganization it was and it is far better important to discuss ethical point of views up from the beginning, at least in academic circles, however, as we know do academic discourses usually sooner or later radiate into the respective practice.

So for almost one decade Middle and East European Countries are involved in a process of economic and political (and, partly in a sense, also cultural) transformation. It is of course a question of at least two different ways (here for the first time in history simultaneously walked on): the one way from planned economy to free market economy and the other way from dictatorship to democracy. And the different countries have made different progress on these ways. The reason is at least partly that the history of these countries was rather different with regard to the economic development (before the communist takeover) as well as to the respective cultural heritage. After the second world war the majority of these countries was occupied by communism - or better, by 
the real existing socialism - without much asking whether the majority of the people of the respective countries would approve this. And, those days the Marxist doctrine, meanwhile translated into public policy by Lenin and Stalin, has already shown its true face. Nevertheless, Marxism itself laid a very high and ethically detailed claim of correction of social conditions. That's why this doctrine is up to now rather attractive for intellectuals all over the world. But there is a difference between good and meant well.

However, it is advisable to distinguish between aims probably held for desirable and steps leading to such an aim. If there are first passed such unpleasant steps as temporary and they finally turn out to be a permanent condition, it needs usually growing social pressure. Certainly, we have to distinguish also between goals we may dream of, but they are finally just unattainable and other goals sounding now and then rather trivial, but they are by way of contrast just feasible. So the question is possibly not how to get rid of power at all (because it is finally impossible), but how to make it tolerable for all (for all, that's important!).

Everybody knows that Marx has passionately slandered because he thought that the prevailing morals is always the morals of the prevailing class, a subtle device of oppression (and this was probably not totally wrong). Marx' aversion of any morals was in fact so strong that he refrained from any considerations with regard to the possible morals of the Labor movement as well as the morals of the socialist and the classless society. This omission should indeed turn out as a bad defect because the "real existing socialism" was ruined not least by a deep moral-crisis.

Each real (and not utopian) society needs (moral) standards and these standards require sanctions and sanctions require any authority to enforce these sanctions if necessary. And accurately that makes the difference. Like capitalism the real existing socialism pretended to require hardly moral virtues, but unlike capitalism it rested on rather idealistic standards (and in this sense comparable to most religions), so it required a very harsh control. The usual consequence of such circumstances are well known: the society becomes double-bottomed, the reality disintegrates into fact and fiction. Exactly that occurred indeed in the East Bloc.

People used to say other things in public than at home or among friends, distrust was prevailing in public, particularly of state authorities, achievements at the working place were less rewarded than any engagement in the party, the black market flourished everywhere, everybody were forced to help oneself as good as possible, etc. etc. And this situation was lasting for decades.

Small wonder that people were stamped also after the turning-point. It is true traditional values were not totally eliminated, but they have been widely undermined. The distrust is deep-seated and often still effective. Many people 
have lost (and the younger people could not at all develop) their moral integrity. But to restore it is a lengthy process, for some people even impossible. Virtues having been clever or even heroically during the time of oppression suddenly became at least reprehensible under the new, changed conditions.

Besides, as already above-mentioned, the different countries of Central- and East-Europe have a different history, a different cultural heritage (religion inclusive) and a different economic development (before the communist takeover). And all these things have obviously long-term-effect. Forty or even seventy years of massive interventions under the "dictatorship of proletariat" had hardly any far-reaching impact against that.

Any far-reaching economic reform - particularly if a totalitarian system was eliminated having held a monopoly with regard to economy and politics - leads to dangerous unstable conditions: prices go up, wages drop down, unemployment is increasing, just before any part of the reform-program becomes effective. Many people suffer the transition to a market economy as a threat to social security. The economic situation deteriorates in the first place, a few people enriches themselves outrageous, criminality (in particular the organized one) is growing and becomes more and more powerful etc. In a word, there is a wide field for ethical considerations. Add to this many (ethical) problems connected with privatization, the sped of transformation and many, many other casuistic problems.

Nevertheless I think there are also other, more far-reaching ethical problems to be solved. It seems to me that most intellectuals in Central- and East Europe see clearer than their colleagues in the West that not only the time of communism is over, but that also the classical capitalism has no future. Certainly, the promising attempt of communism to surmount the boundless capitalism has turned out as a tremendous flop, but this doesn't mean that capitalism (in it's prevailing shape) is actually the best of all possible systems. The recently booming shareholder value shows that the power of capital is meanwhile almost not at all limited. With the threat to move the production in cheaper countries the board of directors of international corporations put employees under pressure. National governments and labor unions are rather helpless. There are two possibilities: either we will have sooner or later the same social conflicts as a century ago or we are able to bring it under control and assign it to the appropriate role: to serve the people and not the other way round. There is a big chance for the countries in transformation, because it is always easier to strike while the iron is hot. 